\title{
ON THE WORK DONE BY PUBLIC ANALYSTS DURING 1882 UNDER THE SALE OF FOOD AND DRUGS ACT.
}

\author{
By G. W. WIGNER.
}

From various causes the annual summary of the results of the Public Analysts' Work has been delayed this year, and as some returns are still missing the analysis cannot be as complete as usual. The preparation of these returns is attended with a good deal of labour, and at times it is impossible that some men can find time for 1t. Thanks are due to those who have done so.

The year which has passed has winessed great strides in the success of the antiadulteration work in the United States, and in France; but elsewhere the condition remains almost as before. The state of things in this country wall be judged best from the following facts and averages.

One step, the necessity for which was urged last year, has been obtained by the action of the Manchester Magistrutes in calling on the referee chemists at Somerset House to attend to endeavour, though unsuccessfully, to support one of their certificates. The provisions for the collection of samples in larger numbers from the more populous districts still remain the great necessity to the proper working of the Act.

The number of returns received of samples analysed and reported upon during the last eight years have been as follows:-

\begin{tabular}{|c|c|c|c|c|c|c|c|c|c|}
\hline \multicolumn{2}{|l|}{ Year. } & \multicolumn{3}{|c|}{ Districts. } & $\begin{array}{l}\text { Samplea } \\
\text { Eamamined. }\end{array}$ & \multicolumn{2}{|r|}{$\begin{array}{c}\text { Samples } \\
\text { Adulterated. }\end{array}$} & & \multirow{2}{*}{$\begin{array}{c}\text { Percentage } \\
\text { Adulte1ated. } \\
1810\end{array}$} \\
\hline $1875-6$ & & $\because$ & 109 & $\because$ & 15989 & $\cdots$ & 2895 & 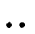 & \\
\hline 1877 & . & .. & 127 & $\cdots$ & 11943 & .. & 2371 & .. & $17 \cdot 70$ \\
\hline 1878 & .. & .. & 168 & $\cdots$ & 15107 & .. & 2505 & $\cdots$ & 16.58 \\
\hline 1879 & .. & .. & 212 & . & 17574 & .. & 3032 & .. & 1725 \\
\hline 1880 & . & $\ldots$ & 237 & $\ldots$ & 17919 & $\ldots$ & 3132 & .. & $17 \cdot 47$ \\
\hline 1881 & $\ldots$ & $\ldots$ & 249 & & 17868 & .. & 2960 & .. & $16 \cdot 56$ \\
\hline 1882 & $\ldots$ & $\ldots$ & 196 & .. & 14900 & $\ldots$ & 2458 & $\ldots$ & $16 \cdot 50$ \\
\hline
\end{tabular}

The diminution in our number of returns is most marked in the Irish ones, but the number of samples reported-nearly 15,000, is quite enough to deduce an average from and show that adulteration is not yet looked upon by all tradesmen in the light of the robbery which it really is.

The percentages of Milk and Groceries purchased are shown in the following table. It is not considered necessary to give the figures for the other varieties of samples.

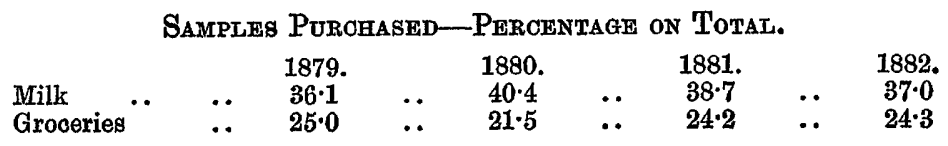


The most important calculation is that which shows the percentage of adulteration actually found on each class of article. To make this clear I reproduce the figures for the five preceding years.

Peroentages of Adulteration mound from 1877 to 1882 , calculated on the number of Samplias of each olass Analysed.

\begin{tabular}{|c|c|c|c|c|c|c|c|c|c|c|c|c|c|c|}
\hline & & & & $\begin{array}{l}1877 \\
26.07\end{array}$ & & $\begin{array}{l}1878 . \\
1838\end{array}$ & & $\begin{array}{l}1879 . \\
22 \cdot 06\end{array}$ & & $\begin{array}{l}1880 \\
22 \cdot 00\end{array}$ & & $\begin{array}{l}1881 . \\
1995\end{array}$ & & $\begin{array}{l}1882 . \\
20 \cdot 35\end{array}$ \\
\hline$B u t$ & .. &. & & $12 \cdot 48$ & . & $13 \cdot 23$ & & 13.93 & & 20.08 & & $12 \cdot 67$ & & $15 \cdot 24$ \\
\hline ries & $\ddot{. .}$ & $\ddot{.}$ & , & 13 &.. & $12 \cdot 89$ & .. & 11 & .. & 10 &. & 9.70 & .. & $10 \cdot 00$ \\
\hline $\mathrm{ru}$ & & & & 23 & & 35 . & & 26 & .. & & 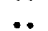 & $19 \cdot 09$ & .. & $I$ \\
\hline Wine, Spir & rits, & $\mathrm{Be}$ & & 47 & & 29 . & & 28 & . & 21 & & 23 & & $21 \cdot 11$ \\
\hline Bread and & Flour & .. & & 6 & & $2 \cdot 97$ & & 4 & .. & $6 \cdot 33$ & . & 4. & $\cdots$ & $4 \cdot 32$ \\
\hline & .. & .. & & $21 \cdot 63$ & .. & 14.98 & & $21 \cdot 45$ & .. & & & $26 \cdot 17$ & .. & $28 \cdot 30$ \\
\hline & .. & - & & & & & & 10 & .. & & 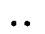 & $5 \cdot 00$ & & $7-03$ \\
\hline & 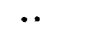 & & $7 \cdot 7$ & & 6. & & 4 & & $17 \cdot 47$ & & $16 \cdot 55$ & & $6 \cdot 50$ \\
\hline
\end{tabular}

The percentage of adulterated Milk is somewhat worse than last year, but the difference is fractional only. The treatment of Milk is exceptionally lenient towards the " trade," since prosecutions are rare for less than ten per cent. of water, and since the Society's limit is a low one, so that probably it is near the truth to say that about 20 per cent. of water is, on the average, added to all the Milk sold.

Butter shows a higher figure, but in nearly every case the report appears to be for the sale of Butterine under the name of Butter instead of admixture.

Groceries are fractionally worse, but the difference is trifling.

Drugs show an improvement of more than 2 per cent., and have fallen to less than half the maximum found in 1878. Still there is room for further care, and it would be well if those pharmaceutical chemists who can test their own drugs satisfactorily did so in a more systematic manner.

Wines, Spirits, and Beer show a fractional improvement which brings them almost to the level of 1880 .

The other items of the table hardly call for remark until we come to the last line, and then it is a wretched conclusion to cume to. Five years work from 1877 to 1882 bas only reduced the average percentage of adulteration by 1.2 per cent, and the last year has only reduced it by 05 per cent.; these results being all obtained on samples purchased by offcers known, and in many cases recognised as officials.

In the Metropolis itself we have reports of the results of 2,364 samples, and the number adulterated is 382 or 16.15 per cent., very nearly 2 per cent. worse than last year.

I have always in these reports made a summary of the "black list," i.e., of Districts which after appointing an analyst ignore the fact and procure no samples, leaving purchasers in the same condition as before. This year the list, as far as we have it, includes three counties and 42 towns all deprived in this way of the benefit of the Act. They do not manage things this way in France or the States, but Public Analysts are powerless in the matter. If the Inspectors will not purchase, nothing can be done but to wait patiently for the needed amendment of the law.

When is this to come?

I am indebted to the Secretaries of the Society, Messrs. Dyer and Hehner, for procuring these returns for the purpose of this summary, and still further to the Analysts who have prepared them. 